\title{
Christian book publishing in the Third World: Some principles, criteria and proposals
}

\author{
by Michael Traber
}

The Cbristian Communication Directory Africa (Paderborn 1980) lists 147 Christian publishing houses in Africa south of the Sahara, of which 108 are Protestant and only 33 Catholic (plus six ecumenical ventures). The statistics of the Directory confirm for Africa what is well known for most parts of the Third World: The Catholic Church has given book publishing a much lower priority than has been the case with the Protestant churches. In many countries of Africa and Asia, Catholic book publishing hardly exists. Only in Latin America is the difference between Protestant and Catholic book consciousness less pronounced. What are the reasons for this? I can think of four. Firstly, Protestantism consists of a multiplicity of churches, many of which were in need of their own publishing houses rather than joining multi-Protestant ventures. This has inflated the figures for Protestant publishing compared to those of the Catholic Church. Secondly, the Catholic missionary church lacked the tradition and example of the great publishing organisations of the Protestant churches. The Society for the Promotion of Christian Knowledge (SPCK), the Christian Literature Society (CLS), the Bible Society and other such bodies established branches throughout Africa and Asia. They not only promoted Christian book publishing, but also taught Africans and Asians how to do it. Thirdly, and most fundamentally, the importance of the Bible in the evangelisation work of the Protestant churches had a direct effect on book publishing in general. Books and bookshops were simply a matter of higher priority for the Protestant churches than they were, and are, for the Catholic Church. Finally, and this may be an accident of history, the Catholic Church was preoccupied with newspapers, magazines and printing presses because, I believe, many of its missionaries came from countries with a strong tradition of the importance of the "Catholic Press": France, Holland, Belgium, Germany, Italy. The ideology of "la bonne presse", so prevalent in these countries, never took root in the predominantly Protestant Anglosaxon countries. There are, according to the Christian Communication Directory Africa, 242 Catholic periodicals and only 131 Protestant newspapers and magazines in Africa south of the Sahara. A similar picture emerges from the statistics for printing presses (74 Catholic, 33 Protestant) ${ }^{2}$.

\section{Printing the church's programme material}

Catholic book production in Africa and Asia was limited to two genres of books: academic studies and practical handbooks for Christians. The first type arose from the need for missionaries to learn foreign languages, many of which had never been written, and to study the history and culture of the people among whom theyworked. This led to many scholarly works in linguistics and social sciences, collections of proverbs and folk tales, and such practical books as grammars and dictionaries. It was the golden age of "academic publishing" by the missionary church, of which we can be rightly proud. But these books were aimed primarily at missionary personnel and interested expatriates.

Dr. Michael Traber, smb, ist Exekutiv Sekretär des "Periodical Development Programme" der Weltvereinigung für christliche Kommunikation (WACC), London. 
The bulk of Catholic publishing was the production of the churches' "programme material", i.e. Bibles, prayer and hymn books, catechisms, etc. It is through these books that the majority of adult Christians were first exposed to script and print. They were used in groups (worship and religious teaching) and they thus blended easily into the oral cultures of black Africa. These books were not aimed at the reading individual but at the participating community. Although such first contacts with the book as an object were culturally attuned and compatible to oral societies, nevertheless there was the disadvantage that in the minds of many the book's "utility" was restricted to worship and learning ${ }^{3}$.

Nobody denies the importance and indeed the need for the Bible and books such as catechisms, manuals of religious instruction, prayer and hymn books, etc. But it is regrettable that hardly anything else was available to the people. There were exceptions to this (especially in Zaire and Zimbabwe), and where the church had its own printing presses some books of a general nature, or religious books, would occasionally be published. This happened when a missionary had written a manuscript or translated a book from a European language and had found the money to have it printed. Sales were handled by the author or by the "procures" of a diocese or religious order. The result of this was that the very concept of publishing remained unknown. It was book printing rather than publishing.

\section{What is Christian book publishing?}

Publishing means to "make public" or to "send forth" among the people the words and pictures which creative or investigative minds have produced, that editors have worked over, that printers have reproduced. It is a formidable succession of activities, none of which, by itself, can be called publishing. It is only when a manuscript has been transformed into a book and distributed and sold, that the process of publishing is complete. Publishing is the whole intellectual and business procedure of selecting and arranging to make a book, and of promoting its ultimate use.

The book, although the product of the manufacturing industry, is not a "consumer good" but an intellectual artifact. Most books are read only once and then kept or passed on to others; a few books become "household articles" and are used frequently. Each product of the publishing industry is different from every other (and this makes a book an artifact), because each book is unique, rendering a unique service to the reader. Therefore each book contains a risk factor: for the customer to buy it, for the retailer to stock it, or for the publisher to invest in it. This makes publishing complex and complicated.

On the other hand, books are not as perishable as many other products; they have a much longer life-time for sale than, for instance, periodicals; but the return from the sale of books is normally slow and therefore much capital is needed for book publishing.

Christian publishing can be seen as an extension of the central mystery of our faith, the Incarnation. Words, which are an actualisation of the Words of God, or a preparation for them, or a concrete application of them, are embodied in print. Christian publishing is, furthermore, an act of Christian witness which is (a) public, because publishing means sending forth words to the public at large; (b) lasting, at least to a certain extent, because books outlive men; and (c) a witness which comprises total Christian living, i.e. the whole man with all his needs. 
There have been cases in history "when books have replaced missionaries"4 but these were rare and limited to certain circumstances (e.g. when no Christian missionaries were allowed to enter a country). The essence of Christian publishing, however, is not merely "preaching through a book" but responding to the message and thus witnessing the faith in the concrete life environment of a community.

At the end of his survey on the Christian publicity media in Africa (Christliche Publizistik in Afrika), Franz-Josef Eilers comes to the following conclusion concerning the role of books:

"On the one hand, the literature of a people provides expression for their innermost feeling, thinking and searching; on the other hand, literature has a moulding power of its own which can influence generations to come.

This is true for literature in general, but may be of particular relevance to the literature of the peoples of Africa. Books written by Africans are bound to make a much greater impact on African readers and are from the point of view of the publicity media of greatest importance for Christianity. The point here is that African literature is no longer in the service of the direct proclamation of the Gospel, but it is an echo of Christian message by its receivers. In their literature we therefore have to a certain extent a mirror of Christianity from the hearts and minds of the 'recipients' of the Gospel - something which, from the point of view of functional publicistics, is sadly lacking in the other media. Our data of (the other) publicity media showed that they were an attempt to 'establish and promote' Christianity rather than reflect it in the African environment."

These words are as true today as they were when first published in $1964^{5}$.

\section{Cultural leadership of the church}

Leadership in most countries of the South has, to a large extent, been identified with political leadership. This is understandable because of the confrontation with the colonial regimes, the struggle for independence, the political fever of the first years of sovereign nationhood, etc. Now the emphasis has begun to shift. Social and cultural leadership are now emerging.

It has often been said that Third World societies were in a cultural crisis and in desperate need of defining and refinding their cultural identities. The crisis is most acute in black Africa, because African culture, language, religion and ethnicity or race have been under attack, or have been treated with contempt, by members of other cultural groups. This is the lingering trauma of the colonial era, with its long history of conquest, slavery, discrimination and large scale destruction of traditional cultures. But cultural identity is also threatened indirectly by the process of modernisation, the introduction of Western technology and the rapid social changes which follow.

In some African countries, especially in francophone Africa, political and cultural leaders have been looking to the church for help in their search for identity. They are aware of the fact that Third World cultural identity is bound up with religion. Religious values have, to a large extent, made Third World persons and their societies what they are. Speaking about Africa, the Ghanaian scholar May Assimeng says that religion was the sine qua non for the rediscovery, assertion and development of African selfhood, African identity and a new African culture. Where religion is 
missing, the African loses his sense of orientation, the group disintegrates, and the nation might develop a substitute in the cult of the national leader or the Party.

The religious/cultural leadership of the Third World will, however, only be acceptable if Christianity can fully meet the spiritual needs enshrined in traditional religions. "(African) religion was, in the first place, power, centre and meaning of life. We (Christians), however, have been put into a straitjacket of do's and don'ts", says the Zairian priest Kalenga Matembele. He adds, "Now that much of Africa has become Christian, Christianity must become African." 6

Christian books could play an important role in the Third World's search for identity. And perhaps the most adequate type of book in the promotion of this process is novels and stories rather than academic treatises. Yet literature deserving of this name is still the most neglected genre in Christian publishing.

\section{Reflection and critical awareness}

The book's privileged role in Christian communication is not merely due to the Bible and the centuries old tradition of religious writing. Books are equally important for the fostering of reflection, critical awareness and for total human development. One of the great hopes for Christianity has been the development of "basic communities in the church" . Basic Christian communities are in line with the best tradition of community life and communal values of. Third World societies. It would be naive, however, to idealise communal values at the expense of the individual's need to reflect and think critically. Third World Christians and Third World societies need both communal values and critical awareness. The book can be an instrument for such reflection because it creates a sense of distance between the surrounding world and the reading person. The book allows the reader to go over the content time and again, at his or her own pace and disposition. It allows the digestion of ideas and the critical assimilation of content more easily than any other media.

But the process of reflection and critical awareness through the book presupposes authors who themselves are reflective and thoughtful. So far the spiritual guides of Africa, for instance, have been a handful of politicians and black authors. The collected speeches of President Nyerere and Prime Minister Mugabe, and the writings of President Kaunda of Zambia and President Banana of Zimbabwe have fulfilled much of the thought provoking function of the book. Critical awareness has also been fostered by some of the South's best novelists. In comparison with these, the church's own spiritual and intellectual guides have been quite ineffective. Here is a field wide open to the church. The Third World's Christian prophets and mystics are still in hiding, i.e. restricted to their local communities. Publishers will have to make them public. And publishing includes the cultivation of authorship.

\section{Literacy, literature and buman development}

One point that has clearly emerged from the development debate of the last two decades is that development is much more than an increase in the GNP. It is an integrated process of economic, social, political, cultural and religious development working in unison. Development is not merely freedom from hunger, disease and oppression. It is the opportunity to make one's own choices and to set one's own priorities. But this presupposes communication. 
There is a general principle of relationship between socioeconomic development and literacy, and the literate environment. From all we know about the factors affecting development, it is evident that literacy, and more particularly a literate environment, play major roles in bolstering and maintaining socio-economic development. We are facing the awesome, but challenging, truth that no society can, in this time and age, make any substantial and long-term progress in the totality of its socio-economic, cultural and political development unless a significant part of society has acquired reading and writing skills and established a literate environment in which the written and printed words become part of the life of the society. The same, I believe, applies to the church community.

In view of this, the church had better revise her communication policy and strategy. If she is to be faithful to her missionary calling, the church can no longer limit book production to her own members, but must provide a genuine service to the community at large. Such a service - so crucial at this point in Third World history - will have to include the systematic promotion of literacy, the provision of follow-up material, the development of children's books, the establishment of small community libraries, book kiosks, and wherever possible book clubs. To pursue such activities the church will need tools. The most important of these will be a real book publishing house.

\section{Developing a book publishing programme}

Publishers do not wait for manuscripts to arrive. They have a "feeling" for topics which are of interest to the people, and they commission books. They are good listeners. They know what people talk about. In other words, they are people orientated rather than message orientated, as is the case with most Christian publishers in the South. Publishers also have to plan years ahead of time and anticipate future events and developments. Years may elapse from the time a book is conceived until it is ready for sale.

There are three types of book for which there is usually an immediate need in societies of the South: the "how-to-do" book, the counselling book, and books of fiction and poetry. The "how-to-do" book responds to the people's natural curiosity and their wish to develop practical skills. Many people in Third World countries seek explanations and guidance to cope with the world that now surrounds them. They want to know more about the diesel engine, money, new cures for illnesses, modern dress, raising pigs, planting cotton, writing letters, citizens' rights - the list is endless.

Counselling books are more than moralistic treatises and sermons in print. They are books that explain and take seriously the myriad problems that have arisen in the wake of rapid social change. Many parents in the Third World no longer understand what is happening to their children. Why don't they want pre-arranged marriages? Why should girls pursue higher education? Why do sons invest their money in savings accounts rather than in a herd of cattle? Why is alcoholism on the increase? Why do peasants grow poorer while the elite amass so much wealth? The modern world is equally bewildering for the young generation. Their parents and families can no longer advise them ${ }^{8}$.

The third and perhaps most important category of books is the novel, short stories, anthologies of poetry: in short, the "narrative" and the "song". The story and the 
song, the oldest and still most effective means of structured communication, have been the vehicles for teaching and entertainment in the past. The story and the poem appearing in print will have to be differently constructed than when they were part of a people's oral literature. But such new literary genres can be developed quite easily. All societies of the South have an abundance of talent in this respect. It seems incredible that the majority of Christian publishers have not yet discovered them. And stories have the advantage that they can be read aloud, recorded on cassettes, broadcasted over the radio, made into plays and even used for films and television.

Finally, it is often forgotten that the book is not just for text but also for pictures. Drawings have been found to be culturally more congruous and more effective than photographs. And no Christian publisher should think that the cartoon-strip is below his or her dignity. They are the Third World's most popular books.

\section{Financial self-reliance and the role of the printing press}

Financial self-reliance is difficult to achieve in any media in the South, but especially in broadcasting and newspaper work. In book publishing, however, it is within reach. Creative and well managed Christian publishing houses in Africa and Asia can attain self-reliance if they have their "bread and butter" line - namely, catechisms, hymn and prayer books and other steady sellers from which they can make a profit. To be profitable they may also need their own retail outlets, bookshops, book-stalls and mail order marketing.

Another source of direct or indirect income can be a printing press. Printing for its own sake and as an end in itself is none of the church's business. The maintenance and development of church-owned printing presses only makes sense if they serve the publishing activities of the church, i.e. printing must be seen as an ancillary activity to publishing, as a service function within the framework of the ministry of the written word.

This does not mean, however, that church-owned printing presses should work exclusively for Christian publishing houses. A delicate balance has to be established between "commercial" and "non-commercial" printing. All those printing jobs which are not in the direct service of the written word (e.g. letterheads, invoice books, etc.) even when ordered by church institutions, should be charged a full or semi-commercial rate. From the profit made from job printing, printshops would be in a position to charge a reduced (non-commercial) rate for jobs which are directly connected with the ministry of the printed word. In this sense, churchowned print-ing presses should be semi-commercial enterprises, making profit from jobbing and thus being able to subsidise Christian publishing.

It is to be regretted that some church-owned printing presses have been reduced to the status of mere industrial enterprises. Their main interest is to make as much money as possible to contribute to the general running cost of a diocese or of an ecclesiastical institution. Capital for the establishment, modernisation or enlargement of church-owned printing presses should be made available only on condition that all profits from printing should be ploughed back into Christian publishing.

Some support agencies have had the policy of subsidising individual titles, and the reasons given for this are normally two: to bring down the retail price of a book so 
that the "poor people" can buy it, and to allow for the printing of a "special book" for which the market is small. There may be justification for both these reasons, but they must be treated as exceptions. Saleability is one of the main criteria of book publishing. If the market for a book is so small that the normal rules of publishing do not apply, the title just should not be printed unless the most extraordinary circumstances prevail. The poverty argument is similar to that of food aid: it may defeat its purpose and become counterproductive if such aid is extended regularly and as a matter of course. Book development, like agriculture, needs incentives of a different kind.

\section{Conclusion}

In recent years the international Catholic media organisations Unda (radio), OCIC (film and audiovisuals), and UCIP (press) have made great strides in their activities in the Third World. In many countries they have developed regional organisations for which they have provided training and professional consultancies. They have also promoted a general awareness among church leaders for their respective media. No such international Catholic organisation exists in the field of book publishing. On the other hand, it is significant that the Protestant churches have had their Agency for Christian Literature Development (ACLD) for a long time, merging in 1975 with the World Association for Christian Communication. The book publishing section of WACC (with its headquarters in London) not only has a highly professional staff but also an annual programme budget of US\$ 1.2 million. It provides its services to both Protestant and Catholic publishing houses or wouldbe publishing houses throughout the Third World.

It would be meaningless to set up an international Catholic organisation for book publishers if the rationale was merely to provide a counterpart to Unda, OCIC, UCIP or the WACC. What is needed is a start at the grassroots, namely in the departments for social communication of the national Bishops' Conferences. Furthermore, Christian book development must develop what already exists - the numerous Catholic printing presses which print but do not publish books. And finally, yet most importantly, church leaders and Catholic funding agencies must become aware of the crucial role the book can play in the development of the Third World church and Third World societies in general.

\section{Footnotes}

1 The following is an abridged version of a lecture given by the author to the meeting of the Curatorium of the Catholic Media Council on 18 May 1981 in Aachen.

2 Both the importance and misere of Christian book publishing and the changing role of the religious book have also been the subject of discussion in West Germany, c.f. "Lesen Buch - Bücherei: Erklärung der Deutschen Bischofskonferenz zur Bedeutung des Lesens und des Buches für den Menschen in Gesellschaft und Kjrche", 1.10.80 in "Communicatio Socialis", Vol. 14,1,1981, pp 88-92, and Ludwig Muth, "Rollenwandel des religiösen Buches": Zu den Ergebnissen einer Infratestumfrage in "Herder Korrespondenz", Vol. 34, No 9, Sept. 1980, pp. 468-471.

3 C.f. my article "Christliche Vorreiter: Beitrag der Kirchen an der Entwicklung des Verlagswesens" in "Börsenblatt für den Deutschen Buchhandel", Frankfurt Nr. 70, Vol. 36 ( 22. August 1980) pp. 2048-2050, in which the churches' historical role of introducing the book 
to many parts of black Africa is emphasised. This has also been documented in a case study: M. Traber, From Printing to Catholic Book Publishing in Uganda, Kampala (Uganda Episcopal Conference) 1975, 79 pp (duplicated).

C.f. Jan Joos, "When books replace Missionaries" in "Christ to World", Rome Vol. XI, No 3 (1966), 209-216.

Franz-Josef Eilers, Christliche Publizistik in Afrika, St. Augustin 1964.

Quoted in and translated from: M. Traber, "Nicht die Lehre, sondern die Praxis ist entscheidend: Afrikanisches Christentum in der Bewährung" in: Afrika den Afrikanern, Vorkoloniales Erbe und nachkoloniale Entwicklung, Frankfurt/M, (Ullstein), 1980, 150.

C.f. "Pro Mundi Vita Bulletin" 81 (April 1980) on "Basic Communities in the Church" and Joseph G. Healey, A Fifth Gospel, The experience of Black Christian Values, Maryknoll, New York, (Orbis), 1981.

8 See "Suggestions for books to be commissioned from Zambian Christians" in: The Lively Word. Christian Publishing and Broadcasting in East Africa, Limbe/Malawi (Popular Publications) $1975,45$.

\section{ZUSAMMENFASSUNG}

Von den 147 christlichen Verlagshäusern Afrikas südlich der Sahara, die im „Christian Communication Directory Africa" (Paderborn 1980) aufgeführt werden, sind 108 evangelisch und nur 33 katholisch. Dies bestätigt auch für Afrika wie allgemein in der Dritten Welt: daß die katholische Kirche offensichtlich der Verlagsarbeit weniger Gewicht beigemessen hat als die protestantischen Kirchen. Dafür gibt es wenigstens vier Gründe: 1. Der Protestantismus besteht aus vielen Gruppierungen, die oft ihre eigenen Verlage haben wollen, statt zusammenzuarbeiten; 2. der katholischen Missionskirche fehlt die Tradition und das Beispiel großer Verlagsorganisationen; 3. die Bedeutung der Bibel in der protestantischen Evangelisation hatte einen mittelbaren Einfluß auch auf die Buchproduktionen allgemein; 4. geschichtlich gesehen war die katholische Kirche mehr mit Zeitungen, Zeitschriften und Druckereien beschäftigt, wohl auch weil viele Missionare aus ihrer Heimat die starke Bedeutung einer „katholischen Presse“ kannten.

Die katholische Buchproduktion in Afrika und Asien beschränkt sich eigentlich im wesentlichen auf zwei Gruppen: akademische Werke und praktische Handbücher für die Christen. Die erstere Gruppe ist notwendig wegen der geschichtlichen und kulturellen Studien der Missionare in ihrem Arbeitsfeld. Die Zielgruppe dieser Publikationen ist das Missionspersonal und interessierte Ausländer. Die größte katholische Verlagsarbeit aber gilt sodann der Produktion von „Programmhilfen“, d.h. Bibeln, Gebet- und Gesangbüchern und Katechismen. Dies sind Bücher nicht für den Einzelnen allein, sondern für das Gemeindeleben. Es ist bedaue rlich, daß sonst kaum etwas für den Leser geschaffen wurde. Ausnahmen gab es dann, wenn kirchliche Druckereien Werke von Missionaren druckten, die selbst schrieben oder europäische Werke übersetzten. Der Verkauf wurde dann oft von dem jeweiligen Autor selbst oder seiner „Prokur“, vom Bistum oder vom Orden durchgeführt. Solche Bücher waren eher ein Druck- als ein Verlagsunternehmen.

Der Verlagsprozeß ist erst dann beendet, wenn ein Manuskript in ein Buch umgewandelt und vertrieben und verkauft wird. Das Verlegen umfaßt den gesamten intellektuellen und geschäftlichen Prozeß der Auswahl und Gestaltung eines Buches, schließlich seinen Vertrieb und Gebrauch. Christliche Verlagsarbeit muß gesehen werden als ein Ausfluß des zentralen Geschehnisses der Inkarnation: Worte, die Gottes Wort aktualisieren und darauf vorbereiten, werden als Druckerzeugnis zugänglich. Christliche Verlagsarbeit ist deswegen ein öffentliches, bleibendes und bezeugendes Geschehen christlichen Lebens. Gerade in Afrika aber sind von einheimischen Autoren geschriebene Bücher auch ein Zeugnis dafür, ob und wie weit christlicher Glaube in ihrem Leben lebendig wird oder geworden ist. 
Auf der Suche nach kultureller und nationaler Identität in Afrika sehen viele Autoren die Notwendigkeit einer kulturellen Führung seitens der Kirche. Afrikanische Gesellschaft ist nicht denkbar ohne Religion und würde ohne sie ihr eigenes Selbst verlieren. Diese religiöse kulturelle Führungsrolle wird aber nur dann angenommen werden, wenn das Christentum die von den traditionellen Religionen geweckten Erwartungen erfüllen kann. Hier könnten christliche Bücher eine bedeutende Rolle spielen.

Bücher sind aber nicht nur wichtig für die Verkündigung; sie sind entscheidend für die Reflexion, das kritische Bewußtsein und die gesamtmenschliche Entwicklung. Ein Buch kann immer wieder gelesen und reflektiert werden, und es steht immer zur Verfügung. Das ist gerade in einer solchen Situation wichtig, wo die Autoren selbst zur Reflexion gezwungen werden, Autoren führen Menschen, wie Bücher afrikanischer politischer Führer inzwischen beweisen, vor allem dort, wo die Kirche noch nicht sehr effizient gewesen ist.

Entwicklung ist nicht nur Freisein von Hunger. Es bestehen tiefe Beziehungen zwischen Entwicklung und Literatur. Ein Leseumfeld trägt bei zur Erhaltung und Entwicklung einer menschlichen Gesellschaft, die sich sonst auf lange Sicht wohl kaum entwickeln kann.

Hier sollte die Kirche ihre Verantwortung für alle Menschen sehen und sich nicht auf innerkirchliche Publikationen beschränken. Dafür braucht die Kirche aber Verlagshäuser.

Für ein Verlagsprogramm kann man nicht auf zufällige Angebote warten. Man muß einen Sinn für das entwickeln, was die Leute brauchen und dann dafür entsprechende Publikationen planen. Vor allem Bücher mit Arbeitsanleitungen, Beratung und Unterhaltung sind in den Entwicklungsländern gefragt. Außerdem sollte man nicht vergessen, daß Bücher sich nicht nur auf Texte beschränken müssen, sondern auch Bilder und Illustrationen (einschließlich Comics!) bringen können.

Finanzielle Unabhängigkeit ist bei publizistischer Tätigkeit in der Dritten Welt bei Zeitschriften und Rundfunk kaum zu erreichen. Gut geleitete Verlage aber könnten finanziell von außen unabhängig werden, wenn eine „Brot und Butter”-Produktion, wie z.B. Katechismen, Gesang- und Gebetbücher aufgenommen wird und vielleicht auch eigene Buchhandlungen und andere Verkaufsmöglichkeiten geschaffen werden. Auch eine Druckerei könnte hilfreich dazu sein. Sie ist aber nur zu verantworten, wenn sie wirklich der Verlagsarbeit der Kirche dient. Dies heißt aber nicht, daß kirchliche Druckereien ausschließlich für kirchliche Zwecke arbeiten sollen. Man muß jedoch für ein entsprechendes Gleichgewicht zwischen kommerziellen und nichtkommerziellen Aufgaben sorgen.

Abschließend ist festzustellen, daß es in der Kirche zwar internationale Organisationen für Presse, Funk und Film gibt, nicht aber für Verlagsarbeit. Wichtig wäre hier vor allem eine entsprechende Aktivität auf nationaler und lokaler Ebene.

\section{RÉSUMÉ}

L'Eglise catholique a donné moins de poids au travail d'édition en Afrique - et également en Asie - que par exemple les Eglises protestantes. La production catholique de livres se limite dans l'ensemble à des études en tant que résultats de l'activité missionaire et à des livres de de poche pour la pratique: bibles, livres de prières et de chants, catéchismes. C'est regrétable. Car on ne peut accepter une conduite culturelle et religieuse que si la chrétienté peut remplir les espérances suscitées par les religions traditionelles. Des livres chrétiens pourraient jouer en cela un rôle important. Et, ici, l'Eglise devrait avoir conscience de sa responsabilité. Mais pour cela, elle a besoin de maisons d'éditions ayant un but bien précis qui soit axé, bien que pas uniquement, sur les intérêts écclésiastiques. En plus de cela, l'activité d'une telle maison d'édition devrait harmoniser le plan national et le plan local. 


\section{RESUMEN}

En Africa - y también en Asia - la Iglesia Católica dió menos importancia que las iglesias protestantes al trabajo editorial. La producción católica de libros se reduce a estudios que son resultado de la actividad misionera y a libros prácticos: biblias, devocionarios, cantorales y catecismos. Todo ello es lamentable, pues sólo se reconocerá a la Iglesia una función directiva si el Cristianismo es capaz de responder a las esperanzas despertadas por las religiones tradicionales. En este contexto podrían jugar un papel importante las publicaciones cristianas. Y por ello la Iglesia debería aquí asumir su responsabilidad. Para ello necesita editoriales, cuya planificación es orientada, aunque no exclusivamente, a intereses eclesiales. Por otra parte esta actividad editorial debería coordinarse a nivel nacional y local.

\section{PERSONALIA}

\section{P. Leo Robert svd $\uparrow$}

Manchem Redakteur der deutschen Kirchenpresse mag er von den gemeinsamen Veranstaltungen im Nachkriegsjahrzehnt in Erinnerung sein. In den letzten Jahren war es um ihn wegen anderer Aufgaben und seiner Erkrankung still geworden: P. Leo Robert, Chefredakteur der Steyler Familienzeitschrift „Stadt Gottes“ von 1937 bis 1941 (Auslandsausgabe) und 1946 bis 1962.

Wenige Monate nach seiner Priesterweihe am 15.5.1931 war der junge Leo Robert aus Sulzbach im Saarland (geb. 4.6.1904) nach Steyl gekommen, um im dortigen Internat die Klassen Unter- und Obertertia zu betreuen. Schon damals zeigte sich seine journalistische und vor allem redaktionelle Begabung: im Mai 1934 veröffentlichte er die erste Ausgabe einer eigenen Schülerzeitschrift für die rund ein halbes Dutzend deutschsprachigen Missionsschulen und Internate der Steyler Missionare. Die vor allem mit Linolschnitten der Schüler, aber auch mit Fotos illustrierte Zeitschrift wurde weithin von den Schülern selbst geschrieben und in der Steyler Druckerei hergestellt. Die erste Ausgabe bezeichnet Robert in einem Begleitbrief als „Probeblätter”: „Als solche nehmt sie hin. Sie sollen Anregung geben und dazu führen, allmählich den gangbarsten Weg herauszufinden . . Unsere Blätter sollen das Spiegelbild unserer Bewegung sein, unseres Lebens und Erlebens. Sie müssen die Ideen künden, die wir tragen und die uns tragen . . "Aus dieser Begründung, die aus der damaligen Lage der katholischen Jugend im wachsenden Machtbereich der nationalsozialistischen „Bewegung” und der Missionsaufgabe der Steyler Missionare („Gesellschaft des Göttlichen Wortes“) zu verstehen ist, wird dann auch der Titel dieser Zeitschrift deutlich: „Heerbann des Weißen Reiters“. So bringt denn auch die Innenseite des Heftes 1934 den für den Titel entsprechenden Text aus der Geheimen Offenbarung des Johannes: „Ich sah den Himmel offen: und siehe ein weißes Roß. Und der auf ihm saß hieß der ,Treue und Wahrhaftige“ . . und sein Name heißt: Wort Gottes .. und aus seinem Mund geht hervor ein zweischneidiges Schwert, auf daß er mit ihm die Völker schlage .. auf seinem Kleid und seinen Hüften steht geschrieben: König der Könige und Herr der Herrscher" (Offb. 19,11-16). Das war in einer Zeit, wo alles andere als die Wahrheit regierte, ein Programm und zugleich eine - aus heutiger Sicht bedrückende - Vision für eine Schülerzeitschrift, die von jenen gestaltet wurde, die wenige Jahre später auf den Schlachtfeldern ihr Leben einsetzten und verloren. In den zunächst viermal jährlich mit 
24 Seiten erscheinenden Heften des „Heerbann“ versuchte Leo Robert dann im Laufe der Jahre mehr und mehr bestimmte Themenkreise aufzuarbeiten, die sich vor allem aus der Situation der Zeit ergaben. So spielt die Königsherrschaft Christi eine besondere Rolle, und ein ganzes Heft wird zum Christkönigsfest 1935 dem Thema „Christusliebe - Christushaß" gewidmet. Über die Hälfte dieses Heftes enthält Gegenüberstellungen von Texten und Illustrationen des Christushasses und der Christustreue. Dabei werden auch Texte der damaligen (nationalsozialistischen) „deutschen Jugend“ und aus dem „Mythos des 20. Jahrhunderts“ zitiert und verurteilt. Das letzte veröffentlichte Heft vom Juni 1938 enthält Hirtenworte der deutschen Bischöfe an die katholische Jugend Deutschlands zum Bekenntnistag 1938 unter dem Thema: Im Kreuz ist Heil. Die letzte Seite dieses Heftes kündigt die nächsten Ausgaben für Februar und April 1939 an. Doch dazu kam es nicht mehr, denn die politischen Machthaber in Deutschland begannen bereits die Missionsschulen aufzulösen. Weil Steyl auf niederländischem Gebiet lag, konnte P. Robert die Schülerzeitschrift mit einigem Mut und (noch) einer gewissen Freiheit redigieren, bis dann die Ereignisse in Deutschland eine Herausgabe unmöglich machten.

Bereits 1937 aber hatte Robert eine weitere, noch wichtigere redaktionelle Aufgabe übernommen: Wegen der Entwicklungen in Deutschland mußte die in Steyl gedruckte Familienzeitschrift „Stadt Gottes“ in einer eigenen Auslandsausgabe für die deutschsprachigen Gebiete außerhalb des (nationalsozialistischen) Reiches redigiert werden. Hier war der dynamische Redakteur an seinem Platz: Immerhin hatte diese Auslandsausgabe, die u.a. in Österreich, der Schweiz, Belgien, Luxemburg, aber auch in Polen und Ungarn verbreitet war, eine Auflage von 110.000 Exemplaren (vgl. CS 11: 1978, 130-133). Als die deutschen Besetzer am 12. Februar 1941 die Steyler Druckerei enteigneten, war auch diese Tätigkeit gewaltsam beendet. Leo Robert wurde Vikar im Westerwald. Er kehrte dann 1946 nach St. Augustin bei Siegburg und später nach Steyl zurück, um hauptverantwortlich die Pressearbeit der Steyler nach dem Kriege wieder aufzubauen. Ab 1949 kann die Familienzeitschrift „Stadt Gottes“ wieder erscheinen. Robert wird Chefredakteur. Bei seinem Ausscheiden aus der Redaktion 1962 hat das Blatt in dem kurzen Zeitraum von 13 Jahren seine höchste Auflage mit monatlich 864.000 Exemplaren (allein für die Deutschlandausgabe!) erreicht. Nach kurzer Seelsorgetätigkeit im badischen Mosbach (1962-1965) kehrt Leo Robert nach Steyl zurück, um sich als Vizepostulator der erwarteten Seligsprechung des Steyler Gründers Arnold Janssen zu widmen, die 1975 erfolgt.

Schon in seiner Schülerzeitschrift „Heerbann" trat Leo Robert kaum namentlich hervor. Immer wieder ermunterte er die Schüler unter dem „Stichwort“ Redaktion, ihre eigenen Beiträge zu schicken und so selbst ihre Zeitschrift zu gestalten. Weshalb nach dem Kriege die von Robert verantwortete „Stadt Gottes“ eine so hohe Auflage erreicht hat, ist wissenschaftlich noch zu untersuchen. Einer der Gründe aber war wohl die Persönlichkeit dieses Mannes, der in seiner freundlichen und optimistischen Art es verstand, den Leser seiner Zeitschrift zu unterhalten, zu formen und ihm in seinem Blatt das Gefühl einer eigenen Familie zu geben. Robert nahm die Erwartungen seiner Leser ernst, ebenso die weltmissionarische Aufgabe jener Gesellschaft, der er sich seit 1924 durch den Eintritt ins Noviziat verschrieben hatte. Am 3. Juli 1981 ist er in Steyl gestorben. Die deutsche katholische Missionspresse hat in ihm einen ihrer Pioniere verloren.

Franz-Josef Eilers (Aachen) 